\title{
Introduction: The Sociology of Migration in Switzerland: Past, Present and Future
}

\author{
Introduction: La sociologie des migrations en Suisse: passé, présent, futur \\ Einleitung: Soziologie der Migration in der Schweiz: Vergangenheit, \\ Gegenwart, Zukunft \\ Milena Chimienti* , Claudio Bolzman*, Didier Ruedin**
}

After 50 years of research and two major research programmes on migration in Switzerland - the NRP 39 Migration and Intercultural Relations and the NCCR on the move - this special issue reflects on the knowledge production, mainly in Switzerland, in this important domain of sociology. What type of research has been produced by sociologists in this field? According to which epistemologies? What public and political impact has this research had? What open questions remain, and in what direction is the sociology of migration likely to move in the future?

At a time when funding sources encourage interdisciplinary research in order to provide a better understanding of social phenomena, it might seem irrelevant to address migration from a single disciplinary angle. We argue, however, that the focus on interdisciplinary research in large research programmes on migration often prevents us from identifying the specificities of sociological research. This might also be a result of the absence of chairs in the sociology of migration in Swiss universities: unlike gender studies, the sociology of migration (and its related fields of citizenship, mobility, diversity, ethnicity and racial studies) remains institutionally marginal in Swiss universities. Yet, as the contributions to this special issue demonstrate, sociological research on migration is thriving in different places.

When social scientists first started to research migration, generating data of various kinds was at the heart of the emerging discipline. In the following, we provide a historical overview of the sociology of migration in Switzerland. Given the profusion of research, our account will not be exhaustive and will invariably omit many important contributions. Yet we believe that this overview will be sufficiently comprehensive for readers to situate the different contributions to the special issue; it should also form the basis for the discussion of open questions for future research in the sociology of migration.

University of Applied Sciences and Arts, School of Social Work HETS/HES-SO, CH-1211 Genève 4, milena.chimienti@hesge.ch, claudio.bolzman@hesge.ch

** University of Neuchâtel, CH-2000 Neuchâtel, and University of the Witwatersrand, didier. ruedin@unine.ch 


\section{From the intrinsic and problematic differences between migrants...}

Studies on migration in Switzerland started in the mid-1960s and early 1970s with medical and economicanalysis to evaluate the costs and benefits of migrants' presence in the short and long term - for instance, the study by Hagmann (1966; see also Fibbi 1989). A sociology of migration only started to develop in Switzerland in the 1970s, coinciding with the legal and political restrictions for migrants examined by Hans-Joachim Hoffmann-Nowotny from the University of Zurich. As was typical of that time, Hoffmann-Nowotny aimed to develop a grand theory explaining the reasons for migration based on a systemic approach, the main focus for which was the major international differences in income which was leading people from poor countries to migrate to richer ones (1973). Migrants therefore represented an underclass which would lead to the proletarisation of migrant workers in the "host" society and to the upward social mobility of the "autochthonous" population (Hoffman-Nowotny 1970). He then concluded that the social position of foreigners in Switzerland was worse than that in their country of origin. Comparing the case of migrants' descendants, he analysed a reproduction of intergenerational social inequalities among the group of people of foreign origin, concluding that young people in this group might eventually only reproduce the subordinate social positions of their parents (Hoffman-Nowotny 1985) - foreshadowing processes of segmented assimilation (Portes and Zhou 1993).

Hoffman-Nowotny was also interested in explaining the impact of migration on the host society and attitudes towards migrants. At the time when immigrants from Southern Europe were still widely regarded as "exotic" amid debates on whether they could ever assimilate, Hoffmann-Nowotny explained their cultural difference to Swiss nationals as being due to structural discrimination against them. Indeed, in his earlier work he argued that the lack of structural integration led to incomplete cultural assimilation and not the contrary. In the 1990 s, however, his views changed and he now argued that migrants were culturally different from the host society; this difference he saw as problematic, preventing migrants from achieving better socio-economic positions. He explained this incompatibility by the fact that migrants were not only unqualified as workers but also came from "predominantly agrarian and often semi-feudal or feudal structures which, from an internal point of view, are still strongly oriented towards the tribe or clan and may be the bearer of religions that have not yet experienced the Reformation and the Enlightenment" (Hoffmann-Nowotny 1992, 74). Because he still regarded socio-economic inclusion as a predictor of cultural assimilation for South-European migrants (HoffmannNowotny 1973) and, given his analysis of the intergenerational reproduction of lower positions among migrants' descendants, he found that this cultural assimilation was impeded. However, in a later study, Hoffmann-Nowotny (2001) revised 
this perspective and concluded that the social distance between "autochthones" and migrants long-resident in the country had actually reduced.

\section{2} ... To the deconstruction of migration as a social problem

As highlighted by Hans-Rudolph Wicker (2003), (sociological) research by Hoffman-Nowotny and other scholars before the 1980s was in concordance with and did not contradict the political problematic vision on "overforeignisation" (Überfremdung). The idea that immigrants are culturally "too different" to assimilate and that there are "too many" of them re-emerged in political discourse in the 1970s (Cattacin and Oris 2013; D’Amato and Ruedin 2018). In the following two decades sociologists started to clearly distance themselves from the political agenda that continued to draw on these ideas.

During the 1980 s, a few projects on migration were developed by sociologists but they were not coordinated, as described by Rosita Fibbi (1989, 148, our translation): "There was no faculty that included this theme in a sustainable way in its teaching or research, apart from the sciences of education at the University of Geneva. Research that is not strictly pedagogical is therefore the result of a more or less fortuitous conjunction of factors, such as a thesis or dissertation at university or social studies institutes, a national research programme (i. e. a budget devoted to the study of a politically burning issue). The migration theme is a poor relation in scientific research (in 1988, the humanities received only 19 per cent of the research credits granted by the Swiss National Science Foundation) [...] in conclusion, scattered research dominated, conducted with relatively limited resources, limited geographically, ad hoc in nature, and with little accumulation of knowledge. It is therefore easy to understand that, under these conditions, the research topics very closely follow the debates and the evolution of immigration policy".

In the early 1980s, important funds were allocated to research on migrants' descendants - the so called "second generation" - leading to three projects on the socio-economic inclusion of and passage from school to the labour market by migrants' descendants (De Rham et al. 1984; Gurny et al. 1984; Hoffman-Nowotny 1985). During this decade, researchers from different disciplines (history, anthropology, geography, law) started to take an interest in migration and it became an established area of research for the Swiss Sociological Association in 1985. ${ }^{1}$ The first article published in the Swiss Journal of Sociology appeared in 1986, written by the coordinators of the new research committee to develop a critical perspective on the production, the legitimation and the meaning of otherness categories (Garcia et al. 1986). Paradoxically it was also in this period that interdisciplinary research started to be encouraged, making it difficult to identify the unique contribution of

1 See: https://www.sgs-sss.ch/de/forschungskomitees/migration-minderheiten/ (11.08.2020). 
sociology. One example of such interdisciplinary work is the collaboration between sociologists and anthropologists in summarising the state-of-the-art in the early 1990s (Wicker et al. 1996). As a cause or consequence of this interdisciplinary work, the focus changed from migrants' difficulties (e.g. school problems, inadaptation) to the problems they may pose in society (xenophobia, national identity), which started a reflection on its own dynamics (Fibbi 1989). Conceptually there was a shift in this period in the terms used to describe this phenomenon - from emigration/immigration to migration - and to grasp it in a more flexible and complete way. This can help us understand the different forms that migration can take - stages/circulation, mono/ multidirectional, forced/voluntary, temporary/long term or international/internal (see Lüthi and Skenderovic 2019; Zufferey et al. 2020).

The 1990s formalised research on migration through the National Research Programme (NRP) 39 "Migration and Intercultural Relations", financed by the Swiss National Science Foundation (SNF). The programme was expected to create "decision-making documents for the political authorities, assistance for social workers responsible for migrants and the opening-up of a more objective public debate on migration" (www.snf.ch). The NRP 39 and its 20+ related projects (Wicker et al. 2003) represent a symbolic recognition of this field of research. In parallel to the NRP 39, an interdisciplinary centre of research and documentation in the field of migration - the Swiss Forum for Migration Studies ${ }^{2}$ - was created with funds from a foundation to carry out research on migration. The different studies of the NRP 39 established migration as a quasi-normal societal phenomenon rather than as a marginal one. These studies focused on the structural barriers to equal treatment, looking at contemporary migration policies, urban and housing conditions and access to labour market and economic positions. A smaller number of studies explored migrants' social, health and educational issues as well as their integration experiences (Wicker et al. 2003). In many ways, the NFP 39 demonstrated how interdisciplinary research can provide a fuller understanding of migration and its challenges.

Migration policy is, of course, the first barrier to equal treatment; to some extent, with its direct democratic system, Switzerland offered a means to represent the national population's preferences Hans Mahnig and his colleagues (2005) identified three trends in the Swiss policy of migration: a policy of laisser-faire, a liberal policy of access motivated by economic and external policy reasons and a restrictive policy of naturalisation following national policy reasons from 1950 to 1980s (Mahnig 1991; Wicker 2003; Ruedin et al. 2015; Piguet 2017). The jus sanguinis citizenship system and low rate of naturalisation led to a high percentage of migrants who were foreign citizens and who whould have disappeared in the statistics of other countries based on jus soli and automatic or facilitated naturalisa-

2 Which became the Swiss Forum for Migration and Population Studies (our emphasis) in 2000 with the arrival of the demographer Philip Wanner and the sociologist and demographer Laurence Charton. 
tion. As highlighted by Wicker $(2003,26)$, Swiss migration policy actively created the "problem of foreigners" with its focus on the dichotomy between citizens and foreigners. Integration became a scientific topic because of the persistence of the foreigner's status and the focus on long established migrants and their descendants, and because the settlement of the "others" was seen as temporary and not aimed at integration (Bolzman et al. 2001; D'Amato 2001; Cattacin and Chimienti 2010). This vision of migration also explains why cultural diversity, ethnicity and racism have remained associated with the issue of foreigners.

The third policy trends started at the end of the 1980s and marked a new logic: whilst access to the country became more restrictive, access to naturalisation was facilitated as of 1992. As a result, migrants were no longer regarded as a homogeneous group considered as "foreigners"; however, the policy change brought a distinction between (desired and sought-after) high-skilled migrants on the one hand, and (unwanted) unqualified migrants on the other. Highly skilled migrants often came from Western (and mostly European) countries and were often long-term residents, while unskilled immigrants and those with few (formal) qualifications - associated with the Global South and often rejected - represented more recent migration (see also Joppke in this special issue; Zufferey et al. 2020). In this context a new asylum law was established in 1981; it was revised many times, mainly in a more restrictive way, underlying the precariousness of this right (Parini and Gianni 2005).

The second structural barrier on which the NFP 39 focused was the economic dimension of migration. This area of research had been relatively neglected by sociologists, except for studies on access to and discrimination on the labour market. Originally, economists provided contrasting results depending on the economic sectors taken into consideration, and whether they took a short- or a long-term perspective. Existing research argued that migrant workers had complementary positions on the labour market and thus neither represented undue competition for "autochthonous" workers, nor led to lower salaries across the economy (Kindlerberger 1967). Research from the NFP 39 expanded this line of inquiry in order to demonstrate that migrants are strongly segregated on the labour market, depending not only on their migratory background but also their residence permit - the more precarious the residence permit, the worse their labour-market position in terms of prestige and salary - and gender, as foreign women were at the bottom of the scale (De Coulon et al. 2003; Flückiger and Ramirez 2003; Kuster and Cavelti 2003). More-recent research shows not only that immigrants are discriminated against in terms of positions and salary but also that their inclusion on the labour market is more difficult (Fibbi et al 2003). On average, migrants have to send 30 per cent more applications to get a job interview (Zschirnt and Fibbi 2019; see also Jann 2014; Auer et al. 2019 for discrimination on the Swiss housing market; and Ossipow et al. 2019 regarding refugees' descendants). 
At the macro level and taking a long-term perspective, the economist George Sheldon explored the effect of migration on the Swiss economy between the 1950s and the 1990s and concluded that it caused a slowdown of the public economy in terms of innovation and growth because liberal Swiss migration policy allowed the entry of many unqualified workers (2003). His analysis supports past and current migration policies of "selectivity", prioritising both qualified and unqualified migrants who support the economy. The long-term analysis, from a sociological angle, of the effect of migration on the national economy might provide a complementary perspective to that of Sheldon by showing that unskilled immigrants and those with little formal education have also enriched the landscape of those small and medium-sized enterprises which are significant for the Swiss economy (Piguet 2005). Moreover, these migrants also helped to streamline the socio-economic structure of Switzerland thanks to the massive entry of their descendants into intermediate white-collar jobs (Bolzman et al. 2003).

The NFP 39 also studied the urban and housing contexts: research showed a similar level of urban segregation of migrants over the years. It also heralded the start of an inversion of minority and majority populations in several urban neighbourhoods inhabited by foreigners or migrants (Huissoud et al. 2003) as well as the phenomenon occurring in popular neighbourhoods whereby the "established" residents are not necessarily Swiss nationals and the "outsiders" are not only new migrants (Wimmer 2003). On the other hand, greater levels of xenophobia in morediverse neighbourhoods compared to more homogenous ones reveals the structural dimension of this phenomenon (Arend 2003; Wicker 2003) although more recent work emphasises the possibilities for contact (see Green et al. 2010). Urban sociologists also highlighted how cities and local policies played key roles in developing integration measures (Cattacin and Kaya 2005; Cattacin 2009).

Microsociology looked at the problems and challenges which migrants experienced in areas such as social support, health or education. During this period a key result of the different studies was that neither the nationality nor the migrants' culture determined their problems and challenges but their socio-economic belonging (Chaudet et al. 2000; Chimienti et al. 2001; Bolzman et al. 2003). The diversification of migrant characteristics in terms of age, gender and legal situation has led researchers to analyse the differences between immigrants and to stop treating them as a homogenous group - a perspective now banished to politics. Since then, studies tend to explore the heterogeneity among immigrants and their descendants, even among migrants of the same national origin (Bolzman 1996; Alber et al. 2000; Bolzman et al. 2001; Frauenfelder 2007; Lieber 2010; Chimienti et al. 2019). In line with a wider recognition of intersectionality, Swiss sociology has demonstrated the specific needs of some migrants at the intersection of unequal power relations. In addition to the classic determinants of social inequality (class, gender and nationality) researchers have begun to analyse the legal dimension of inequality and the 
production of irregularity and marginalisation of asylum-seekers (Efionayi-Mäder et al. 2001), refugees, provisionally admitted foreigners (Achermann and Chimienti 2006), irregular migrants (Chimienti et al. 2003) and, more recently, regularised undocumented migrants (see Jackson et al. 2019) and migrants who depend on social assistance (Bolzman et al. 2002).

The focus on social problems led to researchers exploring migrants' individual and collective resources and understanding them not as passive or the victims of circumstances but as actors (Bolzman and Fibbi 1991; Bolzman 1996; Achermann et al. 2006; Chimienti 2009; Chimienti and Lieber 2019; Mellini et al. 2016). These studies have in common that they demonstrate that formal education and paid work are insufficient to ensure social integration, partly because of a lack of resources but also because of a lack of awareness of the specific needs of migrant populations or populations of foreign origin. It became clear that social integration can only occur structurally and transversally; the acquisition of rights is the best driver of integration, whilst rights are still conceived as an outcome of integration in Switzerland, as illustrated by the naturalisation law (for recent work in this field see, for instance, Hainmueller et al. 2015).

Since the 1980s, researchers have questioned the sedentarity norm in migration policy and earlier studies. They have highlighted the role of legal discrimination, segregation and inequality in migrants' social trajectories, deconstructed migrants as a homogeneous category and shown the diversity of migrants' resources and their forms of mobilisation at the individual and the collective levels. Yet the political impact of these studies remains limited. Whilst a federal law on integration was implemented in 2001, its outreach was sectorial and based on activation policies, demanding more than encouraging the participation of migrants (Bolzman 2002; Cattacin and Chimienti 2009). Integration policy, while allowing more public resources to support migrants' programmes, for some became a policy of control in relation to their legal stabilisation (see, for instance, Bolzman et al. 2002; Borelli et al. in this special issue). Indeed, migrants have to demonstrate their local language skills, employment and financial autonomy if they want to keep or improve their residence permit. Migration and naturalisation laws have become more restrictive in some areas and attempts at coordination in the field of asylum (via, for example, the Dublin agreement) show very unequal treatment between countries. This limited political impact of migration studies in Switzerland has led different scholars to critique knowledge production in this field, smoothing the way for a reflexive turn in migration studies in the subsequent decade. 


\section{The reflexive turn and calls for de-migranticisation}

The questioning of knowledge production concerns both the methods used to generate knowledge, the analysis of the collected information and the transfer of the knowledge. In migration studies, the critique of "methodological nationalism" popularised by Andreas Wimmer and Nina Glick Schiller (2003), though going back to Martins (1974) and Smith (1983) - leads us to question the nation-state as a unit of analysis. Wimmer and Glick Schiller show that this analytical bias, inter alia, in migration studies necessarily describes immigrants as "political security risks, as culturally others, as socially marginal or as an exception to the rule of territorial confinement ... have mirrored the nationalist image of normal life" $(2003,599)$. The argument is that scholarship is often implicit in a "(re)reification of migrants as a distinct category of human mobility" (Lüthi and Skenderovic 2019, 14; see also Poglia Mileti 2000; De Genova 2013; Dahinden 2016).

But how to achieve a "methodological fluidism" and construction of knowledge which would prevent the production of stigmatisation? (Wimmer and Glick Schiller $2003,600)$. The nationalist and sedentarity critique led to a new terminology with which to describe migration. The term mobility helps to encompass a larger group of people (migrants as well as tourists, business people, the armed forces etc.) and the concept of transnationalism enables researchers to emphasise that migration/ mobility is potentially experienced by everyone and connects people beyond national boundaries or across two nations (Kaufmann 2008; Söderström et al. 2013). The concept of "super diversity" coined by Stephen Vertovec (2007) highlights that diversity allegedly reached such a degree that there is now "diversity within diversity" and that the idea of majority/minority social groups is obsolete because groups may contain widely differing statuses within them.

The recognition that mobility and diversity are common human experiences led some researchers to react against the use of the term "migrant" because it was regarded as an external ascription of identity (Yildız 2015). Post-migration perspectives move beyond the widespread use of migration as a relevant demarcation line and "describe cultural, ethnic, religious and national diversity as normality" (Canan and Foroutan 2015, 15). Instead of reaffirming a "migrantology" - the study of migration - in which researchers permanently consolidate their own object of study - the "migrant" as the "other"- post-migration perspectives seek to "overcome such distinctions" (Ring Petersen and Schramm 2017, 6). It is argued that post-migrant and post-ethnic societies should be conceived of as "'societies of negotiation', where former dogmas about 'integration' are challenged and increasingly replaced by struggles over exclusion and inclusion via the renegotiation of hierarchies and through attempts to develop more inclusive notions of who we are" (Foroutan 2016, quoted in Ring Petersen and Schramm 2017, 6). It follows that these terms 
include a normative political vision of "how we want to live together in societies characterized by increasing heterogeneity" (Foroutan 2016, 248).

Some researchers prefer the term "de-migranticisation" to post-migration, following the critique of post-colonial studies which are seen to "still share the discourses and values of (post-)modernity and consequently of coloniality" (Siegenthaler and Allain Bonilla 2019, 5). Decolonial thinking has been theorised as "epistemic disobedience" (Mignolo 2010a) and as "learning to unlearn" (Tlostanova and Mignolo 2012). It therefore means "to change the terms and not just the content of the conversation” (Mignolo 2010b, 313). The de-migranticisation perspective coined by Janine Dahinden (2016) follows the same logic: not just a re-negotiation of power relationships but, in particular, the refusal and denunciation of the inequalities at the root of this social order.

These critiques also lead to "comprehensive analyses of the structures, institutions and discursive frames of the societies of origin and arrival, with their particular local or regional variants, including factors such as industrialization, gender roles, family economies or demographic details" (Lüthi and Skenderovic 2019, 10). These studies reconsider the power relationship in the production of knowledge and encourage the sharing of this power through participative research where actors and "spaces of knowledge" are partners - from the research's conceptualisation to the transfer of knowledge (Dahinden et al. 2020).

Two social-science research programmes financed by the SNF over the past two decades, namely the National Centers of Competence in Research (NCCR) "Overcoming Vulnerabilities: Life Course Perspective” 2010-2021 (hereafter LIVES) and "on the move" (2014-) were developed in this context. The NCCR LIVES emphasised the shared condition of vulnerability of all human beings over the life course, independent of power relationships. One aspect of the research programme "explores the effects of spatial im/mobility on the reconfiguration of gender vulnerabilities. It studies and compares the different forms of spatial im/mobility (expatriation, migration, residential change, educational mobility) in order to establish their links to vulnerability processes", especially the legal and administrative contexts that favour or hinder spatial mobility. The programme also looks at particular periods in the life course, such as the transition to adulthood (Bolzman et al. 2017) or to retirement (Bolzman and Bridji 2019; Ciobanu et al 2019) and their relation with spatial and social im/mobility and vulnerability (Kaufmann and Audikana 2020).

The NCCR on the move focuses more directly on migration and human mobility. Like the NCCR LIVES, the NCCR on the move reflects recent developments in which different approaches now coexist and build on one another. Uniting researchers from across the social sciences and law, some of the projects in the NCCR on the move develop the changes initiated by the reflexive turn, while others take a perhaps more pragmatic approach in order to enhance our understanding of contemporary phenomena related to migration and mobility. It reflects a recent tendency in the 
social sciences to focus on specific social phenomena and societal challenges such as inequality or social cohesion. Less afraid to work with administrative categories and data, such a focus tries to maintain an appropriate distance from political discourse and simplistic descriptions of "problems". Through such an approach, finding solutions to social phenomena like discrimination on the labour market takes precedence over fears of reifying labels and categories which take on a life of their own outside academic research and are therefore "real" in their consequences. With large datasets, access to register data, and new methodologies, the divisions and sub-divisions within the different migrant groups can now be explored without necessarily reifying undue categories. Assumptions such as vulnerability or transnational lifestyles have become expectations that can be tested empirically (Steiner and Wanner 2019; Zufferey et al. 2020).

\section{Open questions and contributions to this special issue}

This overview of (sociological) research on migration has outlined a profound change in the way in which sociologists have approached this phenomenon over time. Much knowledge and data has been generated over the years, although many questions remain unanswered. Today, the need for migration is widely accepted; indeed, international migration has come to represent a central element in the demographic evolution of the countries of the Global North (see, among others, Wanner 2001). Migration, to some degree, compensates for the ageing of the native population and meets the need for labour. At the same time migration, together with other social phenomena, arguably leads to an increasing diversification of the population in Switzerland - which brings questions of social cohesion to the fore and raises new challenges. Here we identify four such challenges related to the production of knowledge, the sovereignty of the state, tensions between protectionism and globalisation, and social cohesion.

The production of knowledge. How can we produce knowledge that will not simply reproduce the national and social order? How can we move beyond nationality-or ethnicity-centred epistemologies? How can we collect data, analyse them and also communicate the results of studies without reproducing unduly homogenous and potentially stigmatising categories?

Crisis in the sovereignty of nation states. The increasing mobility of people, economic globalisation, the international legal framework and the creation of supranational entities like the European Union, as well as transnational risks (epidemics, environmental disasters or terrorism) have all called national sovereignty into question. While migration is not a right and the legal concept of citizenship is still viewed from an assimilationist perspective, these phenomena require consideration of the 
ways of thinking about identity, belonging and participation beyond nation-states, while recognising the important role of states in shaping and implementing policies.

Tensions between protectionism and globalisation. Migrant and immigrant populations are seen both as a threat to the welfare state and as a necessary workforce for the economy and the social security system. Which economic sectors need foreign labour? What is the impact of migrant labour on the economy, the workforce and on innovation and structural change in the long term? How can the economy both defend the national labour market and remain competitive on the global market? How can governments respond to these needs: to be both open and economically attractive to international companies while controlling immigration and/or the different forms of social dumping?

Mobility, diversity and social cohesion. The population has diversified but what forms does this diversification take and how are they experienced on a daily basis? How can we form a political community that reflects the different scales of our memberships and belongings? How does transnationalism create or renew intercultural links and conflicts? What adjustments will cities need to make to cope with mobility and diversity? Who is still defined as a migrant or a foreigner and why? What are the mechanisms that reproduce discrimination and racism in different spheres of social life and how could we tackle them? How can individuals without the protection of a state (exiles, migrants, etc.) claim citizenship rights elsewhere?

The papers in this Special Issue were presented at an international workshop organised at the HETS/HESSO Geneva in December 2018. The Special Issue was then prepared during the confinement that followed the pandemic in early 2020 the guest-editors took this opportunity to reflect on this period. The papers included provide some insights into the questions set out above in an innovative format, as we mixed theoretical articles, more empirically driven articles and a dialogue between two leading scholars in this field: Bridget Anderson and Janine Dahinden. These two scholars were invited to engage with each other's perspectives on the challenges of knowledge production in migration studies. Janine Dahinden argues for the need for "de-migranticisation" in order to avoid the reproduction of social and national order within migration studies. She introduces the concept of the "migrant-citizen nexus" to show that some migrants are granted citizenship whilst some citizens are criminalised or stigmatised. In so doing, she emphasises that the process leading to the production of alterity and sameness shares its logic with national and social order. Bridget Anderson also analysed the many different ways in which migrancy and citizenry are entangled. She shows that the subject making of migrants and of citizens is mutually constitutive. She uses migration as a lens to investigate precarisation, stigmatisation and racialisation processes. She argues that the emphasis on social class in the sociology of migration tends to elude the dynamics of racialisation and as also argued by Saskia Bonjour and Sébastien Chauvin (2018) to naturalize 
classed strategies of mobility. Finally both Anderson and Dahinden discuss the nationalistic policies adopted in reaction to the pandemic.

The contribution by Adrian Favell provides a critique of the sovereignty of nation-states and methodological nationalism. Written in the spirit of the reflexive turn, we believe that this contribution is best read as a manifesto to further unpack the nationalist preconception underpinning the concept of integration. It seeks to abandon the notion of integration in migration studies because it is regarded as a synonym for assimilationism, which in turn reproduces une pensée d'Etat (a state thought) necessarily linked to nationalism. In outlining the argument, the article contends that methodological nationalism underpins the literature on integration and, in some places, conflates early and contemporary strands of the literature for rhetorical reasons. While we recognise that contemporary researchers on integration who focus on societal challenges such as inequality or social cohesion may not feel that their efforts reflect diversity, we encourage scholars of migration to reflect on their use of terminology and how this may affect how we address specific social phenomena.

On the tension between protectionism and globalisation, the different papers in this special issue offer contrasting results, reflecting the current state of affairs in the sociology of migration. For Christian Joppke, protectionism and globalisation can work together in the same neoliberal logic whilst, for Lisa Borelli et al. and Angèle Mendy, these logics enter into conflict and remain unresolved. The article by Erica Righard invites new ways of thinking about social protection in a transnationalised world.

In his paper, Christian Joppke analyses immigration policies in the light of neoliberalism and what he calls "neonationalism". Based on the policies in Western countries and a scholarly and journalistic literature review, Joppke shows that both policies reinforce each other and have the same logic of excluding unqualified migrants whilst recruiting qualified ones - a distinction is thus created between "wanted" and "unwanted" migrants. In this way, protectionism and globalisation follow the same neoliberal logic. He argues that the principle of selection in migration is determined by those skills which push race and ethnicity to the second level, although these phenomena are entangled with social class and thus skills.

On the contrary, the article by Lisa Borrelli, Stefanie Kurt, Christin Achermann and Luca Pfirter argues that much of the tension between protectionism and globalisation remains unresolved. The authors analyse the judgments of the Swiss Federal Supreme Court concerning its refusal to extend a residence permit to any migrant in the last ten years. Based on these judgments, the article shows that a permanent residence permit (Permit C) or an extension of a temporary permit (Permit B) is often denied if the holder is dependent on social assistance (a recognised social right against poverty) for a living. They conclude that the holders of a permanent residence permit and, even more so, those of a temporary permit are not full citizens, 
unlike Swiss natives. The article analyses the arguments in the appeals that justify the revocation or non-prolongation of a residence permit, before concluding that social welfare institutions become a tool for immigration control and make migrants the scapegoats of institutional dysfunction.

In a similar way, Angèle Mendy looks into the policy of labour recruitment in public health in the UK, and shows that the labour policies remain embedded in a nationalist protectionist logic despite the (international) General Agreement on Trade in Services (GATS). National migration policy allows important room for manœuvre in the selection of migrant workers who have, in principle, agreed to remain and work in the UK. In contrast with Joppke's contribution, Mendy argues that the increased restrictions on migrant labour in the health sector - in particular, migrants coming from non-EU/EEA countries - were influenced by ethical issues in the 2000s related to pressure by international public opinion to try to prevent brain drain in the countries of origin. She also shows that the globalised and borderless labour market in the health sector stills functions as long as the presence of migrant workers from the Global South does not conflict with UK immigration policy - which regulates its internal market in favour of national interests - or as long as the migrants are very highly skilled, meaning that high skilled migration has many shapes.

Erica Righard's contribution hints at how we can solve the tension between protectionism and globalisation. Her paper shows the process of transnationalisation of national social policies, looking at the case of the public old-age pension scheme in Sweden. Her article uses an innovative de-nationalised lens through which to analyse the old-age pension - considering various forms of mobility (e/immigration, national and foreign) and public policy responses to these circumstances. This frame raises a different set of questions, seeking to consider who is eligible for the pension questions which are not related to nationality but to the time-space conditions of mobility. For instance, she asks how long after emigration should eligibility expire. How extended is transnational outreach when different countries are implicated because a person has lived, worked and became sick in different countries? Righard shows that these transnational social policies on the public old-age pension have, however, reproduced patterns of global inequality within the national population, excluding those who are not citizens of a country with an international agreement.

Dina Bader and Alexandra Feddersen's contribution investigates how a migrant organisation associated with a right-wing party reconciles its claim to represent immigrants with the party's anti-immigrant agenda. They draw on a content analysis of the websites of two organisations: one associated with a left-wing and one with a right-wing party. The analysis shows that even extreme, opposite positions can lead to internal cohesion through the establishment of distinction - i. e. new hierarchies, including those migrants who were affiliated with the opposite site as the "good" ones, whilst the others are depicted as the "bad" ones. This moves the "blame" to 
others, a process which the authors refer to as "ideological boundary-making". It promotes the formerly excluded, who are now included in the group via a process already well analysed by Ervin Goffman (1996 [1963]) as well as Georg Simmel, looking at newcomers (1979 [1908]). For the party, the inclusion of immigrants may be a way to avoid accusations of xenophobia and racism.

\section{Conclusion: Anchoring the future sociology of migration in the past}

In this introduction to the special issue on the sociology of migration in Switzerland, we have chosen to emphasise the continuous and changing challenges of knowledge production in the sociology of migration. To do so, we took a historical perspective, outlining how contemporary contributions are a development of previous work. While the earliest work on migration closely followed administrative logic, it is because of sociological contributions that we, as a community of social scientists studying immigration and related social phenomena, have developed an independent approach necessary for the scientific study of the subject. On the one hand, sociologists have emphasised the experience of immigrants and their descendants, a strand of the literature that continues today - as several contributions in this special issue demonstrate. On the other hand, sociologists have contributed to the reflexive turn in migration studies, which has questioned how social scientists may be implicit in the different immigrants being presented as a homogenous population with its political consequences. The different contributions to this special issue demonstrate that reflexivity is an ongoing process and show how hard it can be to avoid a nationalist perspective in our research.

Looking at the areas of research over time, we recognise a certain continuity on many topics - for instance, issues of inclusion and exclusion, attitudes towards migrants or the integration of immigrants in various aspects of the everyday. If there is continuity at this level, however, we observe an unprecedented willingness by researchers to challenge earlier perceptions of "immigrants" as a homogenous population - something largely banished to populist political discourse these days. In this sense, as several contributions to this special issue demonstrate, some of the contemporary research in the sociology of migration may appear to have moved closer to the administrative logic of the state so heavily criticised by the reflexive turn. On close examination, however, the focus on specific social phenomena and the dedication to finding solutions to societal challenges such as inequality or social cohesion often allows the necessary distance to be achieved. Better data and methodological advances allow sociologists to acknowledge and study in detail the divisions within larger groups - thus addressing pressing issues of intersectionality.

In this sense, we foresee a healthy future for the sociology of migration in Switzerland, one in which sociological studies provide important contributions to 
interdisciplinary work. On the one hand the focus on specific societal challenges, coupled with better data and methodological advantages, will allow sociologists to move beyond the description of inequalities and exclusion and towards the creation of solutions for an inclusive future. On the other hand, the important voices behind the reflexive turn will continue to warn researchers to stay clear of preconceptions and consider how the social sciences may be complicit in patterns of exclusion. The contributions to this special issue demonstrate that finding solutions to societal challenges and making efforts to view fieldwork, analysis and knowledge transfer through a de-nationalised lens remain formidable challenges that will stay with us in the future.

\section{Acknowledgements}

Our thanks go to those participants in the workshop which we organised in December 2018 who have not been able to participate in this special issue - in particular John Solomos, Maurizio Ambrosini, Ana Paula Beja Horta, Paolo Boccagni, Sébastien Chauvin, Marco Martiniello and João Peixoto; their comments during the workshop were invaluable.

We are grateful to the reviewers of the articles in this special issue for helping us to improve their quality and for their flexibility to work within a very short timeframe. We thank, in particular, Gianni D'Amato for his astute comments and support. Finally, many thanks to Felix Bühlmann for his trust, patience and help in preparing this special issue, as well as Marion Beetschen. This research was supported by the NCCR on the move programme funded by the Swiss National Science Foundation.

\section{References}

Achermann, Christin, and Milena Chimienti, with the collaboration of Stants Fabienne. 2006. Prekarität und Gesundheit. Ressourcen und Risiken von vorläufig Aufgenommenen und Sans-Papiers in Genfund Zurich. Neuchâtel : Forum Suisse pour l'Etude des Migrations et de la Population.

Alber, Jean-Luc, Laurence Ossipow West, Valérie Outemzabet, and Barbara Waldis. 2000. Mariages binationaux. Approches pluridisciplinaires des couples binationaux. Fribourg : Editions Universitaires.

Arend, Michal. 2003. La planification urbaine et la politique du marché du logement peuvent-elles contribuer à une meilleure intégration des migrants? Pp. 227-244 in Les migrations et la Suisse. Résultats du Programme National de Recherche "Migrations et relations interculturelles », edited by Hans-Rudolf Wicker, Rosita Fibbi and Werner Haug. Zurich: Seismo.

Auer, Daniel, Julie Lacroix, Didier Ruedin, and Eva Zschirnt. 2019. Ethnische Diskriminierung auf dem Schweizer Wohnungsmarkt. Grenchen: BWO. https://www.bwo.admin.ch/bwo/de/home/Wohnungsmarkt/studien-und-publikationen/diskriminierung-auf-der-schweizer-wohnungsmarkt. html (25.07.2020). 
Bolzman, Claudio. 1996. Sociologie de l'exil. Une approche dynamique. L'exemple des réfugiés chiliens en Suisse. Zurich: Seismo.

Bolzman Claudio. 2002. La politique migratoire suisse. Entre contrôle et intégration. Ecarts d'identité 99(1): 65-71.

Bolzman Claudio, and Rosita Fibbi. 1991. Collective Assertion Strategies of Immigrants in Switzerland. International Sociology 6(3): 321-341.

Bolzman, Claudio, Rosita Fibbi, and Marie Vial. 2001. La famille: Une source de légitimité pour les immigrés après la retraite? Le cas des Espagnols et des Italiens en Suisse. Revue Européenne des Migrations Internationales 17(1): 55-78.

Bolzman Claudio, Raffaella Poncioni, Sophie Rodari, and Jean-Pierre Tabin. 2002. La précarité contagieuse. Les conséquences de l'aide sociale sur le statut de séjour des personnes de nationalité étrangère. Geneva and Lausanne: Les Editions IES et les Cahiers de l'EESP.

Bolzman, Claudio, Rosita Fibbi, and Marie Vial. 2003. Secondas-Secondos: le processus d'intégration des jeunes adultes issus de la migration espagnole et italienne en Suisse. Zurich: Seismo.

Bolzman Claudio, Laura Bernardi, and Jean-Marie Le Goff (eds.). 2017. Situating Children of Migrants Across Borders and Origins. A Methodological Overview. Dordrecht (NL): Springer Open.

Bolzman Claudio, and Slim Bridji, S. 2019. Older Immigrants Living in Switzerland and Ambivalence Related to Return Around the Retirement Period. International Journal of Comparative Sociology 60(1-2): 14-36.

Bonjour Saskia, and Sébastien Chauvin (2018). Social Class, Migration Policy and Migrant Strategies: An Introduction. International Migration 56(4): 5-18 DOI: 10.1111/imig.12469

Canan, Coşkun, and Naikan Foroutan. 2015. Deutschland postmigrantisch III. Migrantische Perspektiven auf deutsche Identitäten - Einstellungen von Personen mit und ohne Migrations- hintergrund zu nationaler Identität in Deutschland. Berlin: BIM.

Cattacin, Sandro. 2009. Differences in the City: Parallel Worlds, Migration, and Inclusion of Differences in the Urban Space. Pp. 250-259 in Bringing Outsiders In: Transatlantic Perspectives on Immigrant Political Incorporation, edited by Jennifer L. Hochschild, and John H. Mollenkopf. Ithaca: Cornell University Press.

Cattacin, Sandro, and Bülent Kaya. 2005. Le développement des mesures d'intégration de la population migrante sur le plan local en Suisse. Pp. 288-320 in Histoire de la Politique de Migration, d'Asile et d'Intégration en Suisse depuis 1948, edited by Hans Mahnig. Zurich: Seismo.

Cattacin, Sandro and Milena, Chimienti. 2009. Lokale Politik der Eingliederung der Migrationsbevölkerung in der Schweiz. Pp. 655-671 in Lokale Integrationspolitik in der Einwanderungsgesellschaft: Migration und Integration als Herausforderung von Kommunen, edited by Frank Gesemann, and Roland Roth. Wiesbaden: VS Verlag für Sozialwissenschaften.

Cattacin, Sandro and Milena, Chimienti. 2010. Intégration et différence. Une perspective historique et une focalisation sur l'urbain. Pp. 35-43 in Dolmetschen, Vermitteln, Schlichten: Integration der Diversität? edited by Janine Dahinden, and Alexander Bischoff. Zürich : Seismo.

Cattacin, Sandro, and Michel Oris. 2013. Introduction. L'apprentissage de la xénophobie. Pp. 5-12 in La migration italienne dans la Suisse d'après-guerre. Identités, discours et réalités, edited by Morena La Barba, Christian Stohr, Michel Oris, and Sandro Cattacin. Lausanne: Antipodes.

Chaudet, Isabelle, Caroline Regamey, Beatriz Rosende, and Jean-Pierre Tabin. 2000. Migrations et travail social. Lausanne: Réalités Sociales.

Chimienti, Milena. 2009. Prostitution et migration. La dynamique de l'agir faible. Zurich: Seismo.

Chimienti, Milena, and Sandro Cattacin, en collaboration avec Denise Efionayi-Mäder, Martin Niederberger, and Stefano Losa. 2001. "Migration et santé": priorité d'une stratégie d'intervention. Neuchâtel: Forum Suisse pour l'Etude des Migrations et de la Population, SFM Research Report No. 18. 
Chimienti, Milena, and Denise Efionayi-Mäder, avec la collaboration de Romaine Farquet. 2003. La répression du travail clandestin à Genève. Application et conséquences pour les personnes concernées. Neuchâtel: Forum Suisse pour l'Etude des Migrations et de la Population.

Chimienti, Milena, Alice Bloch, Laurence Ossipow, and Catherine Wihtol de Wenden. 2019. Second Generation from Refugee Backgrounds in Europe. Comparative Migration Studies 7(40): 1-15 DOI : $10.1186 / s 40878-019-0138-2$.

Chimienti, Milena and Marylène Lieber 2019. A 'Continuum of Sexual Economic Exchanges' or 'Weak Agency'? Female Migrant Sex Work in Switzerland. Pp. 126-141 in Understanding Sex for Sale. Meanings and Moralities of Sexual Commerce, edited by May-Len Skilbrei, and MarlenSpanger (eds), London: Routledge.

Ciobanu, Ruxandra Oana, Tineke Fokkema, and Mihaela Nedelcu (eds.). 2019. Ageing as a Migrant: Vulnerabilities, Agency and Policy Making. London: Routledge.

Dahinden, Janine. 2016. A Plea for the "De-Migranticization" of Research on Migration and Integration. Ethnic and Racial Studies 39(13): 2207-2225. DOI: 10.1080/01419870.2015.1124129.

Dahinden, Janine, Caroline Fischer and Joanna Menet. 2020. Knowledge Production, Reflexivity, and the Use of Categories in Migration Studies: Tackling Challenges in the Field. Ethnic and Racial Studies 1-20. DOI: 10.1080/01419870.2020.1752926.

D’Amato, Gianni. 2001. Vom Ausländer zum Bürger: Der Streit um die politische Integration von Einwanderern in Deutschland, Frankreich und der Schweiz. Munich: Lit-Verlag.

D’Amato, Gianni, and Didier Ruedin. 2018. Immigration and Populist Political Strategies: The Swiss Case in a European Perspective. Pp. 48-65 in Populism and the Crisis of Democracy: Vol. 3 Migration, Gender and Religion, edited by Gregor Fitzi, Juergen Mackert, and Bryan S. Turner. Abingdon: Routledge.

De Coulon, Augustin, Jean-Marc Falter, Yves Flückiger, and José Ramirez. 2003. Analyse des différences de salaires entre la population suisse et étrangère. Pp. 263-289 in Les migrations et la Suisse. Résultats du Programme National de Recherche "Migrations et relations interculturelles ", edited by Hans-Rudolf Wicker, Rosita Fibbi, and Werner Haug. Zurich: Seismo.

De Genova, Nicholas. 2013. "We Are of the Connections": Migration, Methodological Nationalism, and "Militant Research". Postcolonial Studies 16(3): 250-258.

De Rham, Gérard, Rosita Fibbi, and Olivier Virnot. 1984. L'entrée dans la formation professionnelle. Rapport de recherche sur la formation et l'insertion professionnelles des jeunes étrangers et suisses (FIPES). Lausanne and Geneva: Programme National de Recherche «Education et vie active».

Efionayi-Mäder, Denise, Milena Chimienti, Janine Dahinden, and Etienne Piguet. 2001. Asyldestination Europa. Eine Geographie der Asylbewegungen. Zurich: Seismo, Reihe Sozialer Zusammenhalt und kultureller Pluralismus.

Fibbi, Rosita. 1989. La recherche sur les migrations en Suisse. Revue Européenne des Migrations Internationales 5(3): 148-156. DOI: 10.3406/remi.1989.1981.

Fibbi, Rosita, Bülent Kaya, and Etienne Piguet. 2003. Le Passeport ou le Diplôme ?: Etude des discriminations à l'embauche des jeunes issus de la migration. Neuchâtel: Forum Suisse pour l'Etude des Migrations.

Flückiger, Yves, and José Ramirez. 2003. Positions hiérarchiques et ségrégation par origine en Suisse. Pp. 290-307 in Les migrations et la Suisse. Résultats du Programme National de Recherche « Migrations et relations interculturelles", edited by Hans-Rudolf Wicker, Rosita Fibbi, and Werner Haug. Zurich: Seismo.

Foroutan, Naikan. 2016. Postmigrantische Gesellschaft. Pp. 227-255 in Einwanderungsgesellschaft Deutschland. Entwicklung und Stand der Integration, edited by Heinz Ulrich Brinckmann, and Martina Sauer. Wiesbaden: Springer VS.

Frauenfelder, Arnaud. 2007. Les paradoxes de la naturalisation. Enquête auprès des jeunes issus de l'immigration. Paris: L'Harmattan. 
Garcia, Carlos, Rosita, Fibbi, and Claudio, Bolzman. 1986.Création, légitimation et sens des catégories de l'altérité. Revue suisse de sociologie 12(1): 231-246.

Goffman, Erwin. 1996 [1963]. Stigmate. Les usages sociaux des handicaps. Paris: les éditions de Minuit.

Green, Eva, G.T., Nicole Fasel, and Oriane Sarrasin. 2010. The More the Merrier? The Effects of Type of Cultural Diversity on Exclusionary Immigration Attitudes in Switzerland. Interational Journal of Conflict and Violence 4(2): 177-190 DOI: 10.4119/ijcv-2824.

Gurny, Ruth, Paul Cassée, Hans Peter Hauser, and Andreas Meyer. 1984. Karrieren und Sackgassen: Wege ins Berufsleben junger Schweizer und Italiener in der Stadt Zürich. Diessenhofen: Ruegger Verlag.

Hagmann, Hermann-Michel. 1966. Les travailleurs étrangers, chance et tourment de la Suisse. Lausanne: Payot.

Hainmueller, Jens, Dominik Hangartner, and Giuseppe Pietrantuono. 2015. Naturalization Fosters the Long-Term Political Integration of Immigrants. Proceedings of the National Academy of Sciences of the United States of America 112(41): 12651-12656. DOI: 10.1073/pnas.1418794112.

Hoffmann-Nowotny, Hans-Joachim. 1970. Migration: Ein Beitrag zu einer soziologischen Erklärung. Stuttgart: F. Enke.

Hoffmann-Nowotny, Hans-Joachim. 1973. Soziologie des Fremdarbeiterproblems eine theoretische und empirische Analyse am Beispiel der Schweiz. Stuttgart : Enke

Hoffmann-Nowotny, Hans-Joachim. 1985. The Second Generation of Immigrants: A Sociological Analysis with Special Emphasis on Switzerland. Pp. 109-133 in Guests Come to Stay: The Effects of European Labor Migration on Sending and Receiving Countries, edited by Rosemarie Rogers. London: Routledge.

Hoffmann-Nowotny, Hans-Joachim. 1992. Chancen und Risiken multikultureller Einwanderungsgesellschaften. Berne: Conseil Suisse de la Science, FER-Bericht, ${ }^{\circ} 119$.

Hoffmann-Nowotny, Hans-Joachim (ed.). 2001. Das Fremde in der Schweiz. Zurich: Seismo.

Huissoud, Thérèse, Suzanne Stofer, Antonio Cunha, and Martin Schuler. 2003. Structures et tendances de la différenciation dans les espaces urbains en Suisse. Pp. 175-196 in Les migrations et la Suisse. Résultats du Programme National de Recherche "Migrations et relations interculturelles ", edited by Hans-Rudolf Wicker, Rosita Fibbi, and Werner Haug. Zurich: Seismo.

Jackson, Yves, Delphine S. Courvoisier, Aline Duvoisin, Giovanni Ferro-Luzzi, Patrick Bodenmann, Pierre Chauvin, Idris Guessous, Hans Wolff, Stéphane Cullati, and Claudine Burton-Jeangros. 2019. Impact of Legal Status Change on Undocumented Migrants' Health and Well-Being (Parchemins): Protocol of a 4-Year, Prospective, Mixed-Methods Study, BMJ Open 9(5): e028336. DOI 10.1136/bmjopen-2018-028336.

Jann, Ben 2014. Diskriminierung auf dem Wohnungsmarkt: Untersuchungsergebnisse und Empfehlungen. Bericht von „Stimme dergewählten MigrantInnen für alle“ in Zusammenarbeit mit NCBI Schweiz.

Kaufmann, Vincent. 2008. Les paradoxes de la mobilité: bouger, senraciner. Lausanne: Presses Polytechniques et Universitaires Romandes.

Kaufmann, Vincent, and Ander Audikana. 2020. Mobility Capital and Motility. Pp. 41-47, in Handbook of Urban Mobilities, edited by Ole B. Jensen, Claus Lassen, Vincent Kaufmann, Malene Freudendal-Pedersen, and Ida Sofie Gøtzsche Lange. London and New York: Routledge.

Kindlerberger, Charles P. 1967. Europe's Postwar Growth: The Role of Labour Supply. Cambridge: Harvard University Press.

Kuster, Jürg, and Guido Cavelti. 2003. Le recrutement de la main-d'oeuvre étrangère. Effets des règlements du droit des étrangers et du droit d'asile. Pp. 247-262 in Les migrations et la Suisse. Résultats du Programme National de Recherche " Migrations et relations interculturelles", edited by Hans-Rudolf Wicker, Rosita Fibbi, and Werner Haug. Zurich: Seismo.

Lieber, Marylène. 2010. Du diplomate à l'expatrié. Les migrations chinoises en Suisse. Revue européenne des migrations internationales 26(2): 191-214. 
Lüthi, Barbara, and Damir Skenderovic. 2019. Changing Perspectives on Migration History and Research in Switzerland: An Introduction. Pp. 1-30 in Switzerland and Migration, Historical and Current Perspectives on a Changing Landscape, edited by Barbara Lüthi, and Damir Skenderovic. Cham: Springer/Palgrave Macmillan.

Mahnig, Hans 1991. La politique suisse à l'égard des étrangers. Unpublished Master thesis. Paris: Institut d'études politiques de Paris.

Mahnig, Hans (ed.). 2005. Histoire de la politique de migration, d'asile et d'intégration en Suisse depuis 1948. Zurich: Seismo.

Martins, Herminio. 1974. Time and Theory in Sociology. Pp. 246-294 in Approaches to Sociology: An Introduction to Major Trends in British Sociology, edited by John Rex. London: Routledge and Kegan Paul.

Mellini, Laura, Francesca Poglia Mileti, and Michela Villani. 2016. Migrantes et séropositives en Suisse: Les stratégies de l'agir secret. ¿ Interrogations ?, 22 June, L'enquêteur face au secret, http://www. revue-interrogations.org/Migrantes-et-seropositives-en (25.07.2020).

Mignolo, Walter D. 2010a. Epistemic Disobedience, Independent Thought and Decolonial Freedom. Theory, Culture \& Society 26(7-8): 159-181.

Mignolo, Walter D. 2010b. Delinking: The Rhetoric of Modernity, the Logic of Coloniality and the Grammar of De-Coloniality. Pp. 303-368 in Globalization and the Decolonial Option, edited by Walter D. Mignolo, and Arturo Escobar. London: Routledge.

Ossipow, Laurence, Anne-Laure Counilh, and Milena Chimienti. 2019. Racialization in Switzerland: Experiences of Children of Refugees from Kurdish, Tamil and Vietnamese Backgrounds. Comparative Migration Studies 7(19): 1-17. DOI: 10.1186/s40878-019-0117-7.

Parini, Lorena and Gianni, Matteo. 2005. Enjeux et modifications de la politique d'asile en Suisse de 1956 à nos jours. Pp 189-252 in Histoire de la politique de migration, d'asile et d'intégration en Suisse depuis 1948, edited by Mahnig Hans. Zurich: Seismo.

Piguet, Etienne. 2005. Les migrations créatrices. Etude de l'entrepreneuriat des étrangers en Suisse. Paris : L'Harmattan.

Piguet, Etienne. 2017. L'Immigration en Suisse : soixante ans d'entrouverture. Lausanne : Presses Polytechniques Romandes.

Poglia Mileti, Francesca. 2000. Les catégories de la migration. Enjeu social ou référent identitaire? Revue suisse de sociologie 26(1): 3-35.

Portes, Alejandro, and Min Zhou. 1993. The New Second Generation: Segmented Assimilation and its Variants. The ANNALS of the American Academy of Political and Social Science 530(1): 74-96.

Ring Petersen, Anne, and Moritz Schramm. 2017. (Post-)Migration in the Age of Globalisation: New Challenges to Imagination and Representation. Journal of Aesthetics \& Culture 9(2):1-12. DOI: 10.1080/20004214.2017.1356178.

Ruedin, Didier, Camilla Alberti, and Gianni D'Amato. 2015. Immigration and Integration Policy in Switzerland, 1848 to 2014. Swiss Political Science Review 21(1): 5-22. DIU 10.1111/spsr.12144.

Siegenthaler, Fiona, and Marie-Laure Allain Bonilla. 2019. Introduction: Decolonial Processes in Swiss Academia and Cultural Institutions. Empirical and Theoretical Issues. Tsantsa 24(1): 4-13.

Simmel, George. 1979 [1908]. Digressions sur l'étranger. Pp. 53-77 in L'école de Chicago: naissance de l'écologie urbaine, edited by Grafmeyer Yves and Isaac, Joseph. Paris : Ed. Du Champ Urbain.

Sheldon, George. 2003. L'impact de la main-d'oeuvre étrangère sur les salaires relatifs et la croissance en Suisse. Pp. 322-354 in Les migrations et la Suisse. Résultats du Programme National de Recherche "Migrations et relations interculturelles ", edited by Wicker, Hans-Rudolf, Rosita Fibbi, and Werner Haug. Zurich: Seismo.

Smith, Anthony D. 1983. Nationalism and Classical Social Theory. The British Journal of Sociology 34(1): 19-38. DOI: 10.2307/590606. 
Söderström, Ola, Shalini Randeria, Didier Ruedin, Gianni D’Amato, and Francesco Panese (Eds.). 2013. Critical Mobilities. Abingdon: Routledge.

Steiner, Ilka, and Philippe Wanner (eds.). 2019. Migrants and Expats: The Swiss Migration and Mobility Nexus. New York: Springer.

Tlostanova, Madina V., and Walter D. Mignolo. 2012. Learning to Unlearn: Decolonial Reflections from Eurasia and the Americas. Columbus: Ohio State University Press.

Vertovec, Steven. 2007. Super-Diversity and its Implications. Ethnic and Racial Studies 30(6): 1024-1054. DOI: $10.1080 / 01419870701599465$.

Wanner, Philippe. 2001. Immigration en Suisse. Situation et caractéristiques démographiques. Neuchâtel: OFS.

Wicker, Hans-Rudolf. 2003. Introduction: migration, politique de migration et recherche. Pp. 11-62 in Les migrations et la Suisse. Résultats du Programme National de Recherche "Migrations et relations interculturelles», edited by Hans-Rudolf Wicker, Rosita Fibbi, and Werner Haug. Zurich: Seismo.

Wicker, Hans-Rudolf, Jean-Luc Alber, Claudio Bolzman, Rosita Fibbi, Kurt Imhof, and Andreas Wimmer (Eds.). 1996. Das Fremde in der Gesellschaft. Migration, Ethnizität und Staat. Zurich: Seismo.

Wicker, Hans-Rudolf, Rosita Fibbi, and Werner Haug (eds.). 2003. Les migrations et la Suisse. Résultats du Programme National de Recherche "Migrations et relations interculturelles». Zurich: Seismo.

Wimmer, Andreas. 2003. Etrangers établis et outsiders indigènes. Pp. 197-226 in Les migrations et la Suisse. Résultats du Programme National de Recherche "Migrations et relations interculturelles", edited by Hans-Rudolf Wicker, Rosita Fibbi, and Werner Haug. Zurich: Seismo.

Wimmer, Andreas, and Nina Glick Schiller. 2003. Methodological Nationalism, the Social Sciences, and the Study of Migration: An Essay in Historical Epistemology. International Migration Review 37(3): 576-610.

Yıldız, Erol. 2015. Postmigrantische Perspektiven. Aufbruch in eine neue Geschichtlichkeit. Pp. 19-36 in Nach der Migration. Postmigrantische Perspektiven jenseits der Parallelgesellschaft, edited by Marc Hill, and Erol Yildız. Bielefeld: Transcript.

Zschirnt, Eva, and Rosita Fibbi. 2019. Do Swiss Citizens of Immigrant Origin Face Hiring Discrimination in the Labour Market? Working Paper \#20 February, 2019. NCCR On the Move and Université de Neuchâtel, https://nccr-onthemove.ch/wp_live14/wp-content/uploads/2019/02/ nccrotm-WP20-Zschirnt-Fibbi_Feb19.pdf (25.07.2020).

Zufferey, Jonathan, Ilka Steiner, and Didier Ruedin. 2020. The Many Forms of Multiple Migrations: Evidence from a Sequence Analysis in Switzerland, 1998 to 2008. International Migration Review. DOI: $10.1177 / 0197918320914239$. 